\title{
Contributions of Periwinkle Shell Ash on the Stability and Elastic Properties of Modified Asphalt Concrete for a High Trafficked Road
}

\author{
Amadi-Oparaeli, Kemejika Ichechi*, Miefama Oju, Igwe, Aleruchi Enwuso \\ Department of Civil Engineering, Rivers State University, Nkpolu Oroworukwo. Port Harcourt, Rivers State, \\ Nigeria. \\ *Corresponding Author: Kemejika Ichechi, Department of Civil Engineering, Rivers State University of \\ Science and Technology, Port Harcourt, Rivers State, Nigeria
}

\begin{abstract}
The adverse environmental impact of industrial and agricultural waste/by-products combined with the rising cost and difficulty in obtaining construction materials have influenced research into better ways to manage these wastes/by-products by incorporating them in asphalt concrete mix design.Different researches have shown that some agricultural waste/by-products can be included as mineral fillers in hot-mix asphalt concrete to obtain certain desirable properties. It is on this basis that this research attempts to investigate the effect of Periwinkle Shell Ash(PSA) on the mechanical and elastic properties of asphalt concrete, which will serve as basis for the use of such materials in pavement construction. An experimental approach was adopted to achieve this goal using the Marshal Mix design method topreparerepresentative samples. Stability and flow were obtained using the Marshal apparatus, while the Asphalt Institute Model was used to obtain the dynamic modulus of the samples for both un-soaked and soaked conditions. The results show that the mechanical properties, such as stability, density, flow, air voids, tensile strength, and tensile and compressive strains obtained from the modified HMA concrete was better than that of the conventional (unmodified) HMA concrete due to the addition of Periwinkle Shell Ash. However, 2.5\% PSA content by weight of aggregates is the threshold content to attain maximum values of stability and tensile strength.The Elastic properties such as Dynamic Modulus E* (which relates to the stiffness of the HMA concrete), Elastic modulus, and Poisson's ratio obtained from the modified HMA concrete significantly improved upon addition of PSA. However, while the dynamic modulus increases linearly with increasing PSA content, the filler must not exceed $2.5 \%$ by weight of aggregates at in order to achieve maximum elastic modulus.
\end{abstract}

Keywords: Periwinkle Shell Ash, Asphalt Concrete, Compressive Strain, Dynamic Modulus, Tensile Strength

\section{INTRODUCTION}

Continuous generation of wastes arising from industrial by-products and agricultural residue, create acute environmental problems both in terms of their treatment and disposal. The construction industry has been identified as one of the areas where the waste can be absorbed, with the majority of such materials identified as fillers useful in concrete (Antiohos et al., 2005). If these fillers have pozzolanic properties, they impart technical advantages to the resulting concrete and also enable larger quantities of cement replacement to be achieved (Hossain, 2003). Appropriate utilization of these materials brings ecological and economic benefits sincerecycling waste materials into useful products has becomeone of the most proactive and efficientmethods of solving waste disposal problems (Ahmed, Ayman \& Afaf, 2006). Recycling is a process of changing waste materials into new products to prevent hazards associated withwaste, reduces the consumption of fresh raw materials, and it also reduces greenhouse gas emissions arising from the conventional method of disposing such wastes (Grosse, 2010). Many researchers have been conducted to determine ways of improving the properties of asphalt concrete to meet the ever changing conditions of loading, environment, as well as cost of construction. Studies have been conducted to determine the effects of different types of mineral fillers on asphalt concrete mix properties. For example, Cabeza et al. (2010) suggest that mineral fillers (e.g. cement dust, quarry dust, fly ash, etc.) are unique in their ability to allow porous materials to become stronger by filling the pores and voids on the surface of such materials. 
Huang, Bird, \& Heidrich (2007) and Al-Saffar (2013), have conducted experiments on the incorporation of several types of mineral filler into asphalt in its mix design; including lime stone powder, waste glass, and quarry dust. Cabeza et al. (2010) indicates that there are several other filler materials usable in construction (e.g. ceramic, bricks, Portland cement, fly-ash, lime etc.). Furthermore, there is a wide range of combined materials, which are manufactured by processing different material ls from different origins so as to be able to improve structural performance when in use (Fassi \& Maina, 2009). The present study is aimed at investigating experimentally the contributions of Periwinkle Shell Ash as mineral filler in Asphalt Concrete Mixtures, especially the stability characteristics. This is important because of the following reasons: Also this study therefore will enhance their perception of Periwinkle shell ash as mineral filler asphalt in pavement construction, and expose significant quality specifications worthy of consideration in practice.

\section{Materials AND Methods}

Sources of the materials used and the various testing procedures which are performed in compliance with standard specifications such as ASTM, British Standards, Indian Standards and AASHTO are described. The procedure for Marshall Mix design is also outlined.

\subsection{Sample Collection}

The materials used for this research includes fine and coarse aggregates, bitumen, and filler. The fine aggregate used was sharp sand, with specific gravity of 2.66, while the coarse aggregate was all-in graded gravel with specific gravity of 2.78, and having maximum size of a half-inch $(12.7 \mathrm{~mm})$. These aggregates were obtained from the local building materials market at Mile-3, Diobu, Port Harcourt, Rivers State, Nigeria. Laboratory tests carried out on the aggregates included the following:

Gradation analysis(Sieve Analysis)

\subsection{Specific Gravity Test}

The binder used was grade 60/70 penetration bitumen as recommended by ASTM D1559 for Highway Pavements. This binder was obtained from Julius Berger Construction Company Port Harcourt, Rivers State, Nigeria. Within the scope of this study, the tests carried out on binder included;

- Specific gravity Test

- Penetration Test

- Viscosity Test

- Softening Point Test.

The filler used was Periwinkle Shell Ash, obtained from the local materials market at Mile-3, Diobu, Port Harcourt, Rivers State, Nigeria. Only Specific Gravity test was carried out on the pozzolan.

\subsection{Specific Gravity of Periwinkle Shell Ash}

For the mineral filler, the pycnometer method was used to obtain the weight of a given volume of the modifier and also used to obtain the weight of an equal volume of water. Specific gravity was thus obtained by dividing the weight of the modifier by the weight of an equal volume of water.

\subsection{Presentation of the Models Used}

This section highlights the models used in the determination of the mechanical and elastic properties of the modified and unmodified asphalt concrete in addition to the conventional density-voids analysis. The Stability and flow results were obtained using the Marshall apparatus, which simultaneously displays the loading applied to the samples as well as their displacements via an attached Linear Variable Displacement Transducer (LVDT).

The mechanical and elastic properties were determined using models as prescribed in various textbooks. The Dynamic Modulus was obtained using the Asphalt Institute Model. The Asphalt Institute Model (1993) developed by the Asphalt Institute, gives a method for design in which the dynamic modulus is determined, as presented in Huang's Pavement Analysis and Design textbook (1993). The model is given below; 


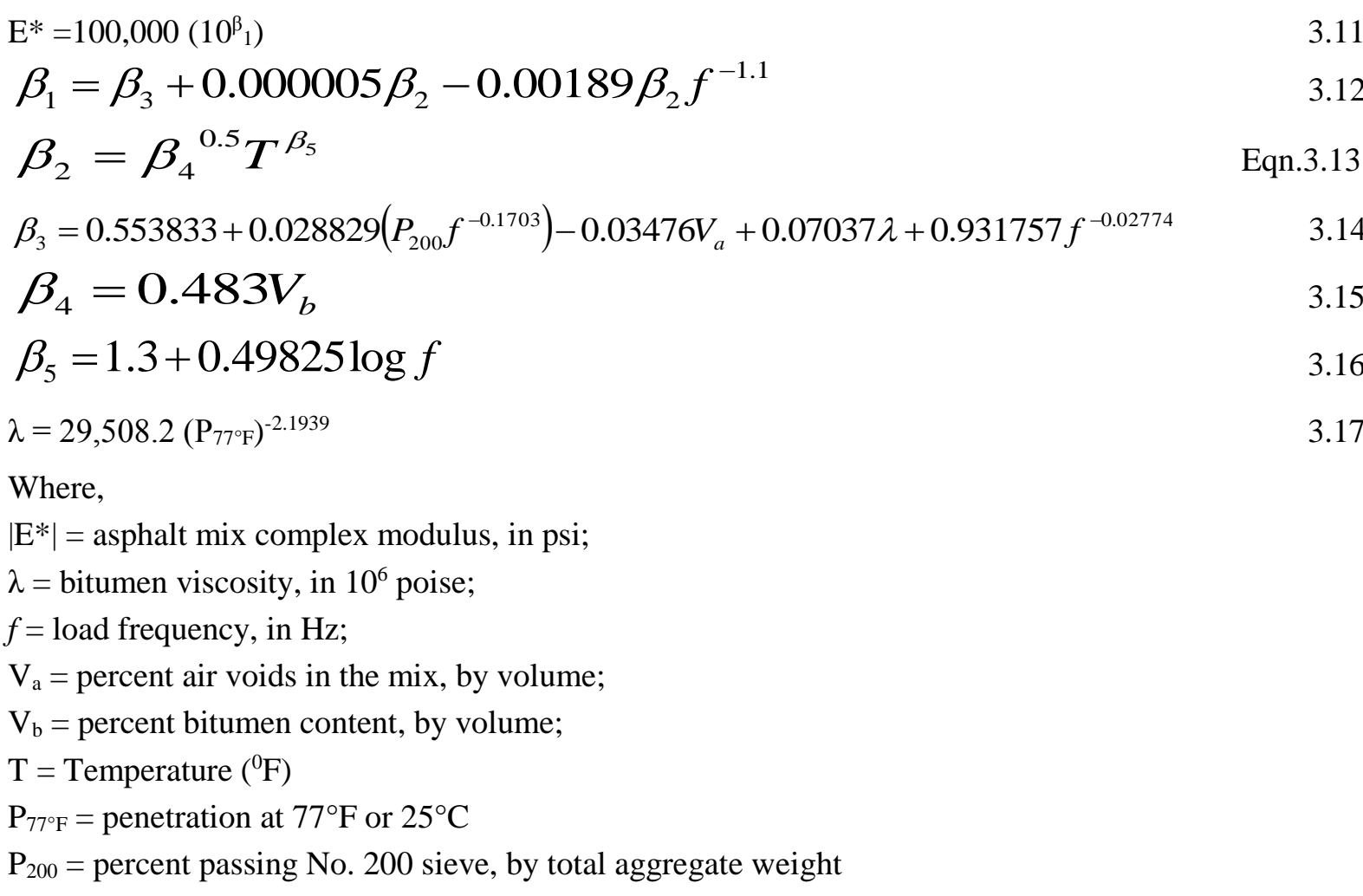

The model for Elastic modulus, tensile and compressive strength, and Poisson's ratio are given in the equations below:

$$
\begin{aligned}
& \mathrm{E}=\frac{1}{\varepsilon x}(\sigma x-\mu \sigma y) \\
& \sigma x=\frac{2 P}{\pi t d} \\
& \sigma y=\frac{-6 P}{\pi t d} \\
& \mu=\frac{\varepsilon x}{\varepsilon y}
\end{aligned}
$$

Where,

$\mathrm{E}=$ asphalt mix elastic modulus, in Mpa; $\varepsilon \mathrm{x}=$ tensile strain of sample, $\sigma \mathrm{x}=$ Tensile stress of sample, $\sigma \mathrm{y}=$ Compressive stress of sample, $\mu=$ Poisson's ratio of sample, $\mathrm{P}=$ Stability of sample

$\mathrm{t}=$ Thickness of sample, $\mathrm{d}=$ Diameter of sample

These models were programmed into a Microsoft excel worksheet to make its computations more efficient. Gradation of Aggregates, Mix proportion, Results and Graphs of the focused properties versus modifier content were produced and their analysis is given.

\subsection{Grading of Aggregates}

The gradation analysis procedure involves separating a sample of dry fine or coarse aggregates of known mass through a set of sieves in order to determine the grading (the particle size distribution) of the coarse and fine aggregates as specified by ASTM C136-01 (BS: 410-69). Dry samples of the aggregates were weighed and then placed on the set of sieves stacked in order of increasing sizes. The sieves were then agitated for at least two minutes and the mass retained on each sieve was weighed. The percentage passing percentages were calculated and recorded. The particle size distributions were then obtained graphically by plotting the percentage passing each sieve against the corresponding sieve size. 
Contributions of Periwinkle Shell Ash on the Stability and Elastic Properties of Modified Asphalt Concrete for a High Trafficked Road

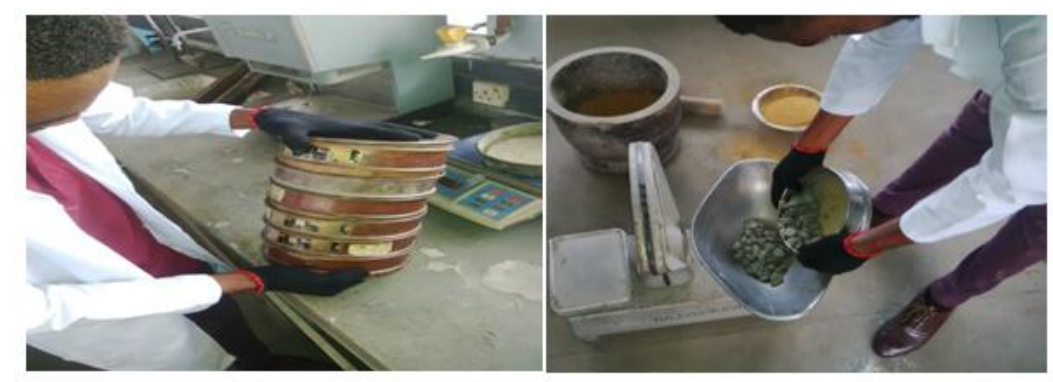

Figure1. Aggregate Sieving operation

Table1. Gradation of Sand (Sample Size $=1200 \mathrm{~g}$ )

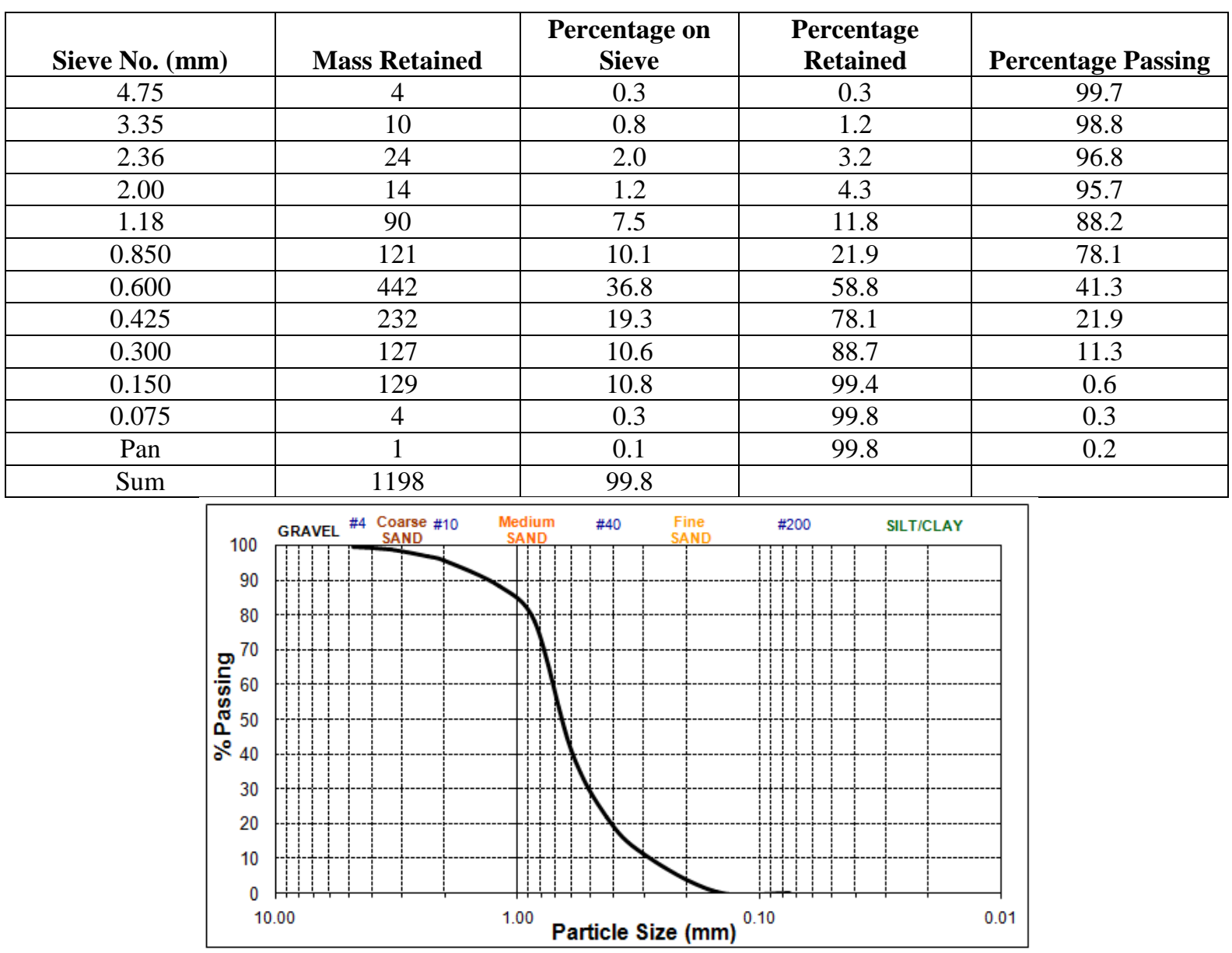

Figure2. Particle Size distribution for Sand

Table2. Gradation of Gravel (Sample Size $=1200 \mathrm{~g}$ )

\begin{tabular}{|c|c|c|c|}
\hline Sieve No. $(\mathbf{m m})$ & Mass Retained & Percentage on Sieve & Percentage Passing \\
\hline 25.4 & 0 & 0.0 & 100.0 \\
\hline 19 & 0 & 0.0 & 100.0 \\
\hline 13.2 & 106.5 & 8.9 & 91.1 \\
\hline 9.5 & 573.6 & 47.8 & 43.3 \\
\hline 6.7 & 317.8 & 26.5 & 16.8 \\
\hline 4.75 & 99.1 & 8.3 & 8.6 \\
\hline 3.35 & 60.8 & 5.1 & 3.5 \\
\hline 2.36 & 5.3 & 0.4 & 3.1 \\
\hline 1.18 & 4.8 & 0.4 & 2.7 \\
\hline 0.425 & 10.2 & 0.9 & 1.8 \\
\hline 0.3 & 0 & 0.0 & 1.8 \\
\hline 0.075 & 15 & 1.3 & 0.6 \\
\hline Sum & 1193.1 & 99.9 & 99.4 \\
\hline
\end{tabular}


Contributions of Periwinkle Shell Ash on the Stability and Elastic Properties of Modified Asphalt Concrete for a High Trafficked Road

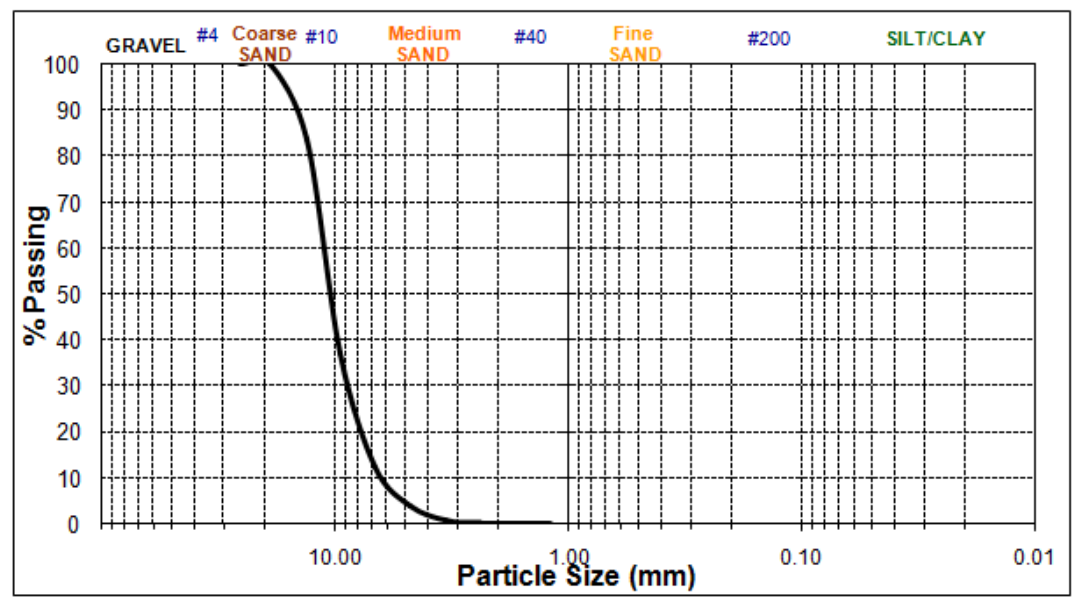

Figure3. Particle Size distribution for Gravel

Table3. Schedule of Mix proportion for Aggregates

\begin{tabular}{|c|c|c|c|c|c|c|}
\hline $\begin{array}{c}\text { Sieve } \\
\text { (in.) }\end{array}$ & $\begin{array}{c}\text { Sieve } \\
(\mathrm{mm})\end{array}$ & $\begin{array}{c}\text { Specification } \\
\text { Limit }\end{array}$ & $\begin{array}{c}\text { \% passing } \\
\text { Aggregate A } \\
\text { (Gravel) }\end{array}$ & $\begin{array}{c}\text { \% passing } \\
\text { Aggregate B } \\
\text { (Sand) }\end{array}$ & $\begin{array}{c}\text { Mix Proportion } \\
(0.60 A+0.40 \mathrm{~B})\end{array}$ & Tolerance \\
\hline $3 / 4 "$ & 19.1 & 100 & 100.0 & 100.0 & 100.0 & \pm 6 \\
\hline $1 / 2 "$ & 12.7 & $76-92$ & 91.1 & 100.0 & 94.7 & \pm 6 \\
\hline $3 / 8 ”$ & 9.52 & $64-79$ & 43.3 & 100.0 & 66.0 & \pm 5 \\
\hline No. 4 & 4.75 & $40-60$ & 8.6 & 99.7 & 45.0 & \pm 5 \\
\hline No. 10 & 1.18 & $23-37$ & 2.7 & 87.4 & 36.6 & \pm 4 \\
\hline No. 40 & 0.425 & $7-20$ & 1.8 & 21.2 & 9.6 & \pm 4 \\
\hline No. 80 & 0.300 & $5-13$ & 1.8 & 10.6 & 5.3 & \pm 3 \\
\hline No.200 & 0.075 & $3-8$ & 0.6 & 0.3 & 0.5 & \pm 1.5 \\
\hline
\end{tabular}

Table4. Mix Properties for Unmodified Asphalt Concrete

\begin{tabular}{|c|c|c|c|c|c|c|}
\hline $\begin{array}{c}\text { Binder } \\
\mathbf{\%}\end{array}$ & $\mathbf{G}_{\mathbf{m b}}$ & Stability (N) & $\begin{array}{c}\text { Density } \\
\left(\mathbf{k g} / \mathbf{m}^{\mathbf{3}}\right)\end{array}$ & Flow (mm) & VTM (\%) & VMA (\%) \\
\hline 4 & 2.181 & 13335 & 2181 & 1.745 & 10.70 & 17.42 \\
\hline 4.5 & 2.259 & 17410 & 2259 & 2.33 & 6.42 & 14.49 \\
\hline 5 & 2.274 & 24305 & 2274 & 2.68 & 4.68 & 13.91 \\
\hline 5.5 & 2.290 & 28852 & 2290 & 2.695 & 2.87 & 13.29 \\
\hline 6 & 2.194 & 15767 & 2194 & 2.975 & 5.88 & 16.94 \\
\hline
\end{tabular}
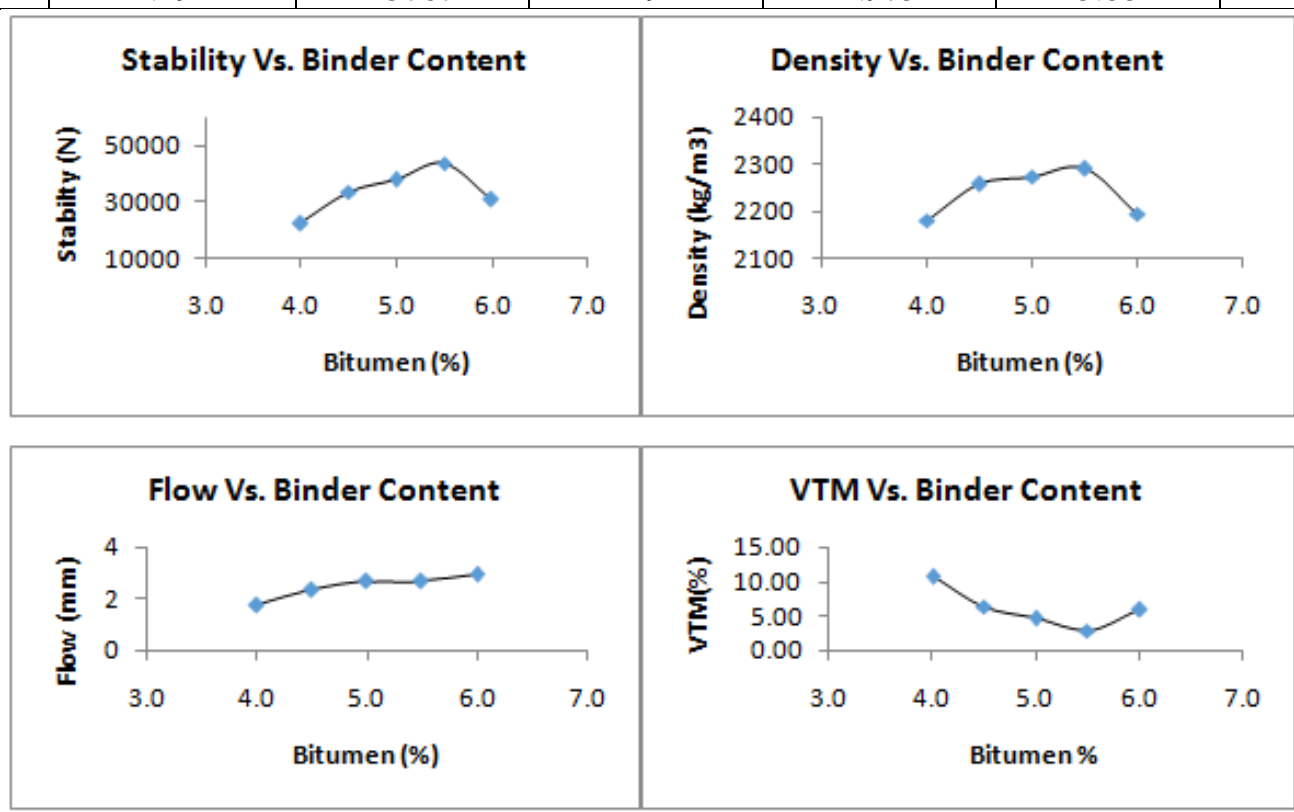

Figure4. For Optimum Asphalt Content 
Contributions of Periwinkle Shell Ash on the Stability and Elastic Properties of Modified Asphalt Concrete for a High Trafficked Road

Table5. Variation of Strength Properties of Modified Asphalt Concrete at varying PSA contents

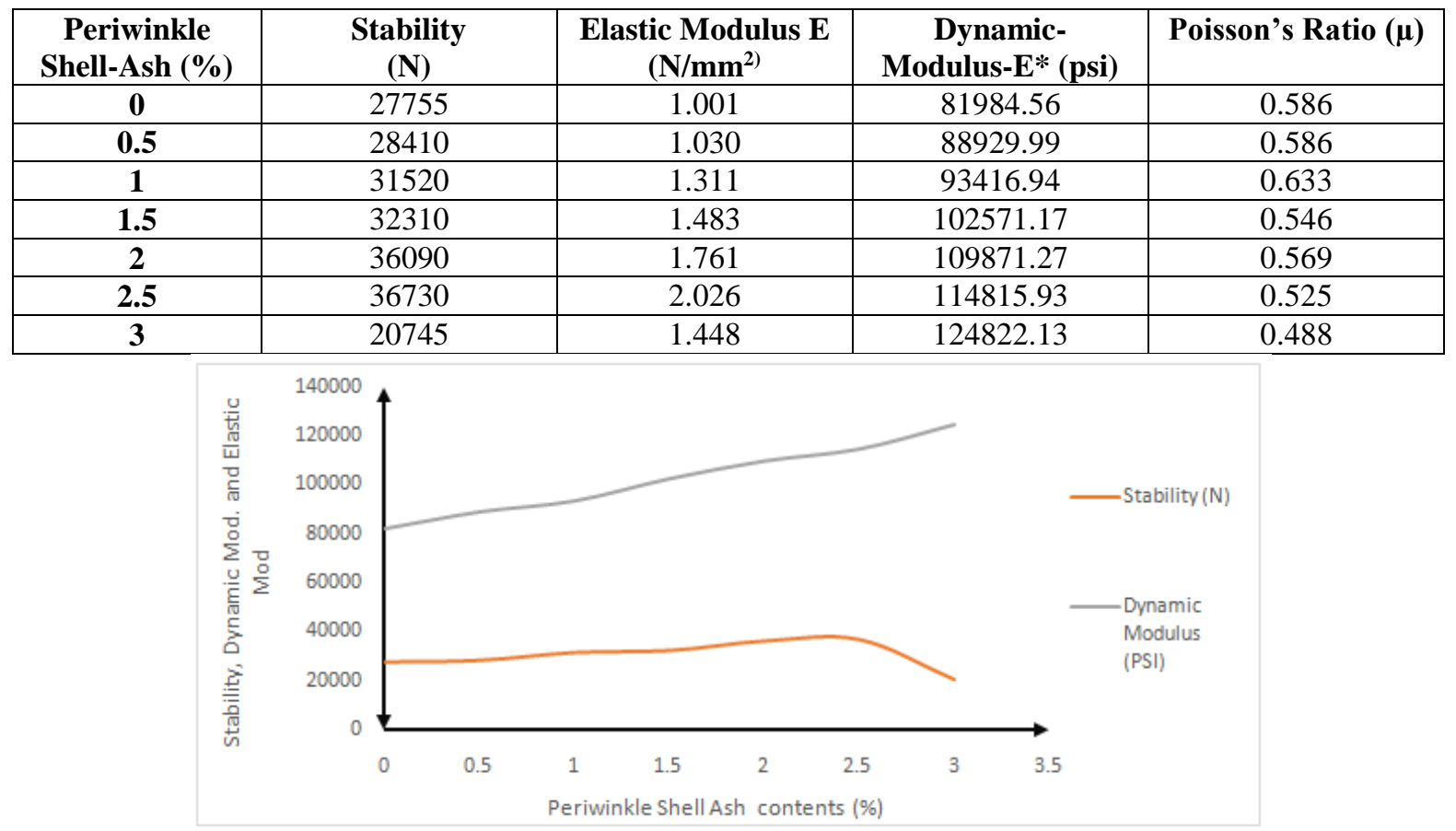

Figure5

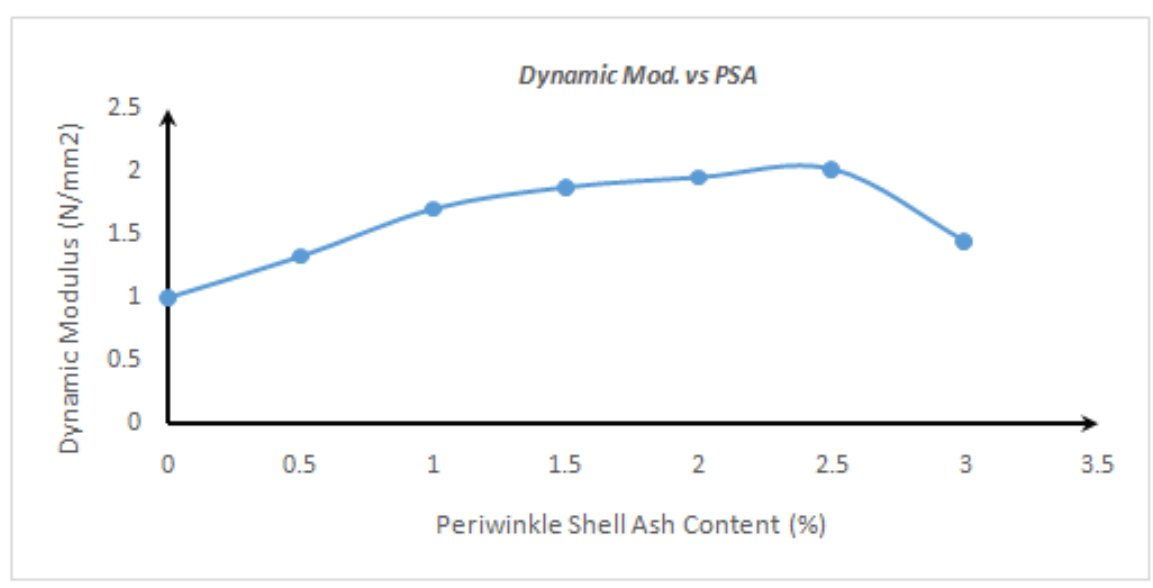

Figure6

\section{RESULTS AND DISCUSSION}

The technical presentation of the results and analysis of the experiments conducted for this research. It concentrates on the changes in the stability and key elastic properties with respect to addition of Periwinkle Shell Ash (PSA). These results are tabulated and graphical representations are provided where necessary. Other parameters of the unmodified asphalt concrete such as stability, density, flow, and air voids were also considered.

\subsection{Variation of Stability Property at Varying PSA Content}

Figures 5 illustrate the Stability behaviour of the modified mixes with respect to various PSA contents. As illustrated in the above figure, it is seen that for the modified mixes stability increases by $2.4 \%$ from $27755 \mathrm{~N}$ for the unmodified mix to $28410 \mathrm{~N}$ upon addition of $0.5 \%$ PSA. Addition of $1 \%$, $1.5 \%, 2 \%$ and $2.5 \%$ PSA further increased stability by $13.6 \%, 16.4 \%, 30 \%$ and $32.3 \%$ to $31520 \mathrm{~N}$, $32310 \mathrm{~N}, 36090 \mathrm{~N}$ and $36730 \mathrm{~N}$ respectively. However, at 3\% stability reduced by $25.3 \%$ to $20745 \mathrm{~N}$; indicating that further increase in PSA content would cause a corresponding decrease in the stability of the modified asphalt concrete mix. This may be because the load bearing aggregates has been reduced following the in the fine (PSA) contents; and the mixture has become brittle, thus the mix becomes weak to resist axle loads. 


\subsection{Variation of Elastic Modulus (E) at Varying PSA Content}

As illustrated in figure 6, Elastic modulus (E) of the asphalt concrete showed almost identical set of values for the various PSA contents. Elastic modulus increased by $2.9 \%$ from $1.001 \mathrm{MPA}$ for the control sample, to $1.030 \mathrm{MPA}$ at $0.5 \%$ PSA content. This value further increased by $31.1 \%$ to 1.311 MPA at $1 \%$ PSA content; by $48.3 \%$ to $1.483 \mathrm{MPA}$ at $1.5 \%$ PSA content; by $76.1 \%$ to $1.761 \mathrm{MPA}$ at $2 \%$ PSA content; and peaks by $202.6 \%$ to 2.026 MPA at $2.5 \%$ PSA content. However, the value of elastic modulus drops to $1.448 \mathrm{MPA}$ at $3 \%$ PSA content, indicating that further addition of PSA filler would cause a corresponding decrease in the value of elastic modulus of the mix.

\subsection{Variation of Dynamic Modulus $\left(E^{*}\right)$ at Varying PSA Content}

As illustrated in figure 5 the Dynamic Modulus( $\left(\mathrm{E}^{*}\right)$ at a load frequency of $10 \mathrm{~Hz}$ increased linearly with increasing PSA content. From Table 5, it is seen that compared with the control mix, the dynamic modulus E* increased by $8.5 \%$ from 81984.56 PSI for the unmodified mix to 88929.99 PSI upon addition of $0.5 \%$ PSA. Dynamic modulus further increased by $13.9 \%$ to 93416.94 PSI at $1 \%$ PSA content; increased by $25.1 \%$ to 102571.17 PSI at $1.5 \%$ PSA content; increased by $34 \%$ to 109871.27 PSI at 2\% PSA content; increased by $40 \%$ to 114815.93 PSI at $2.5 \%$ PSA content; and increased by $52.2 \%$ to 124822.13 at $3 \%$ PSA content. This indicates that increase in PSA content caused a corresponding increase in the stiffness of the modified asphalt concrete mix. This increasing stiffness may be as a result of the increase in bulk density of the mix resulting from the addition of PSA.

\section{CONCLUSiON}

A review of related literature shows that although a lot of research has been conducted with respect to using alternative materials for improving pavement performance, more still needs to be done as pavement performance is subject to the prevailing conditions in different geographical locations.

The conclusions drawn from this research are based on the aim and general finding of the project. While the aim of this research was based on unraveling the effect of Periwinkle Shell Ash on the mechanical and elastic properties of HMA concrete, the results obtained were able to help identify this effect. Thus, the following conclusions have been drawn:

The mechanical properties such as stability, density, flow, air voids, obtained from the modified HMA concrete was better than that of the conventional (unmodified) HMA concrete due to the addition of Periwinkle Shell Ash. However, 2.5\% PSA content by weight of aggregates is the threshold content to attain optimum values of stability and tensile strength.

The Elastic properties such as Dynamic Modulus E* (which relates to the stiffness of the HMA concrete), Elastic modulus, and Poisson's ratio obtained from the modified HMA concrete significantly improved upon addition of PSA. However, PSA content must not exceed $2.5 \%$ by weight of binder at optimum in order to achieve maximum elastic modulus.

\section{RECOMMENDATION}

Since the analysis of mechanical and elastic properties for the modified HMA concrete showed improved performance of the pavement due to addition of Periwinkle Shell Ash, the following recommendations are provided considering the scope, limitation and general findings:

- Periwinkle Shell Ashcan serve as an excellent material for the modification of HMA concrete for such desirable properties as improved stability, stiffness, durability, and resistance to stripping.

\section{REFERENCES}

[1] Afolayan, O. D., \& Abidoye, O. A. (2017). Causes of failure on Nigerian Roads: A review. Journal of Advancement in engineering and Technology, 5(4): 1-5.

[2] Ahmad, J., Yusoff,N.I.M., Hainin,M.R., Rahman,M.Y.A.,\&Hossain, M. (2014). Investigation into hot-mix asphalt moisture-induced damageunder tropical climatic conditions.Construction and Building Materials 50 (2014)567-576.

[3] Ahmed, Y.A. Ayman, M.O. and Afaf, A. M. (2006). Effect of Using Waste Cement Dust as Mineral filler on the Mechanical properties of Hot Mix Asphlat. Ass. Uni. Bull Environ. Res. Vol. 9 No. 1 pp. 55-59. 
Contributions of Periwinkle Shell Ash on the Stability and Elastic Properties of Modified Asphalt Concrete for a High Trafficked Road

[4] Antiohos, S.; Maganari, K.; Tsimas, S. (2005), "Evaluation of blends of high and low calcium fly ashes for use as supplementary cementing materials", Cement \& Concrete Composites, Vol. 27, pp. 349-356.

[5] Airey, G.D., Singleton, T.M., \& Collop, A. (2002). Properties of Polymer Modified Bitumen after RubberBitumen Interaction. Journal of Materials in Civil Engineering, 14(4):344-356

[6] Airey, G.D. (2004). Styrene-Butadiene-Styrene Polymer Modification of Road Bitumen. Journal of Materials Science 39:951-959

[7] Al-Qaisi T.A.. (1981). The Effect ofMineral Filler on the Asphalt Paving Mixtures, M.Sc. Thesis, College of Engineering, University of Baghdad, 1981.

[8] Al-Saffar, A.H. (2013). The Effect of Filler Type and Content on Hot Asphalt Concrete Mixture Properties. College of Engineering, University of Mosul 2013.

[9] Alvarez, A.E., Ovalles, E. \& Caro, S. (2012). Assessment of the effect of mineral filler on asphaltaggregate interfacesbased on thermodynamic properties. Construction and Building Materials, 28, 599606

[10] American Association of State Highway and Transportation Officials (AASHTO). (2000). AASHTO Provisional Standards, April 2000 Edition. Washington, D.C.

[11] ASTM (2001). Standard Test Method for Density, Relative Density (Specific Gravity), and Absorption of Fine Aggregate. ASTM C128 - 01. ASTM International, West Conshohocken, PA.

[12] ASTM (2001). Standard Test Method for Density, Relative Density (Specific Gravity), and Absorption of Coarse Aggregate. ASTM C127 - 01. ASTM International, West Conshohocken,PA.

[13] ASTM (2001). Standard Test Method for Sieve Analysis of Fine and Coarse Aggregate. ASTM C136 - 01. ASTM International, West Conshohocken, PA.

[14] ASTM (2003). Standard Test Method for Density of Semi-solid Bituminous Materials (Pycnometer Method). ASTM D70 - 03. ASTM International, West Conshohocken, PA

[15] ASTM (2004). Standard Test Method for Resistance to Plastic Flow of Bituminous Mixtures Using Marshall Apparatus. ASTM D 1559 - 76. ASTM International, West Conshohocken, PA

[16] ASTM (2006). Standard Test Method for Viscosity Determination of Asphalt. ASTM D $4402-6$. ASTM International, West Conshohocken, PA

[17] ASTM (2010). Standard Test Method for Bulk Specific Gravity and Density of No-Absorptive Compacted Bituminous Mixtures. ASTM D2726 - 10. ASTM International, West Conshohocken, PA.

[18] ASTM (2011). Standard Test Method for Standard Penetration Testand Split-Barrel Sampling of Soils. ASTM D1586 - 11. ASTM International, West Conshohocken, PA.

[19] ASTM (2013). Standard Test Method for Penetration of Bituminous Materials. ASTM D5/D5M-13. ASTM International, West Conshohocken, PA.

[20] ASTM (2013). Standard Specification for Penetration-Graded Asphalt Cement for Use in Pavement Construction.ASTM D946-09, ASTM International, West Conshohocken, PA.

[21] ASTM (2014). Standard Test Method for Softening Point of Asphalt and Pitch. ASTM D3461 - 14. ASTM International, West Conshohocken, PA.

[22] ASTM (2018). Standard Terminology Relating to Materials for roads and Pavements. ASTM D8-18. ASTM International, West Conshohocken, PA.

[23] Bari, J. \& Witczak, M.W. (2006) "Development of a New Revised Version of the Witczak E* Predictive Model of Hot Mix Asphalt Mixtures", Journal of the Association of Asphalt Paving Technologist, 75,381-424.

[24] Bocci, M., \& Giuliani, F. (1998). Caratterizzazione di filler per conglomerati bituminosi. In Proceedings of the XXIIIConvegno Nazionale Stradale AIPCR, Verona, Italy, 18-21 May 1998.

[25] British Standard Institution (1990) Methods of Test for Soils for Civil Engineering Purposes. BS 13772:1990 London: British Standards Institution

[26] British Standards Institution (1993). Methods of Test for Petroleum and its Products. BS 2000-49:1993 London: British Standards Institution

[27] British Standard Institution (2007) Bitumen and Bituminous Binders: Measurement of density and specific gravity. BS 2000-549:2007 London: British Standards Institution

[28] Button, J.W., \& Little, D.N. (1987). Asphalt Additives for Increased Pavement Flexibility, Texas Transportation Institute, College Station, TX, November, 1987.

[29] Cabeza, L.F., Castell A., Medrano M., Martorell I., Pérez G., \& Fernández I. (2010). Experimental study on the performance of insulation materials in Mediterranean construction. Energy and Building, 47: 630636 
Contributions of Periwinkle Shell Ash on the Stability and Elastic Properties of Modified Asphalt Concrete for a High Trafficked Road

[30] Caltrans Division of Maintenance (2007). Flexible Pavement Preservation. Maintenance Technical Advisory Guide, 1(2): 1-28

[31] Emesobi, F.C. (2000). Testing and Quality Control of Materials in Civil and Highway Engineering. Port Harcourt: Goodnews Printing Press.

[32] Fassi, A., \& Maina, L. (2009). L'isolamento eco-efficiente. 2nd edition. Milano: Edizioni Ambiente; 2009.

[33] Grabowski, W. \& Wilanowicz, J. (2008). The structure of mineral filler and their stiffening properties in filler bitumenmastics. Construction and Building Materials, 41, 793-804.

[34] Grosse, F. (2010). Is Recycling Part of the Solution? The role of recycling in an expanding society and a world of finite resources.

[35] Hossain, K. M. A. (2003), "Blended Cement using Volcanic Ash and Pumice", Cement and Concrete Research, Vol. 33, pp. 1601-1605.

[36] Harris, B.M. \& Stuart, K.D. (1995). Analysis of mineral fillers and mastics used in stone matrix asphalt, Association of Asphalt Paving Technologists, Williamsburg, VA, 1995

[37] Hicks, R.G., Curren, P., \& Lundy, J.R. (2003). Asphalt Paving Design Guide. Oregon: Asphalt Pavement Association of Oregon

[38] HP Corporation. (no date) HP Bitumen Handbook. [PDF]Mumbai: Hindustan Petroleum Inc.

[39] Huang, Y., Bird, R.N., \& Heidrich, O. (2007). A review of the use of recycled solid waste materials in asphalt pavements. Resources, Conservation and Recycling, 52(1): 58-73.

[40] Huang, B.; Shu, X.; Chen, X. Effect of mineral fillers on hot-mix laboratory measured properties. International Journal of Pavement Engineering, 8, 1-9.

[41] Indian Standards (1978). Methods for Testing Tar and Bituminous Materials. IS: 1201-1220 (1978). New Delhi: Bureau of Indian Standards

[42] Indian Standards (2007). Methods of Test for Aggregates for Concrete. IS: 2386 (2007). New Delhi: Bureau of Indian Standards

[43] Kandhal, P.S. \& Parker, F. (1998). Aggregate Tests Related to Asphalt Concrete Performance in Pavements; NCHRP Report405; National Academy Press: Washington, DC, USA, 1998.

[44] Keneth, G.O. (2012). The Use of Periwinkle Shell Dust as Mineral Filler in Asphalt Mixture. Unpublished M.Sc. Thesis, Department of Civil Engineering, Ahmadu Bello University, Zaria.

[45] Kosmatka, S.H., Kerkhoff, B., \& Panarese, W.C. (2008). Design and Control of Concrete Mixtures. EB001, 14th Ed. Portland Cement Association, Illinois, USA, 2002.

[46] Lanier, D. (1998). Heavy oil-a major energy source for the 21st century. In 7th UNITAR Heavy Crude and Tar Sands International Conference, Beijing.

[47] Little, D.N. \& Petersen, J.C. (2005). Unique effects of Hydrated Lime Filler on the Performance-Related Propertiesof Asphalt Cements: Physical and Chemical Interactions Revisited. Journal of Materials in Civil Engineering, 17, 207-218.

[48] Mehari, Z. B. (2007). "Effect of Different Types of Filler Materials on Characteristics of Hot-Mix-Asphalt Concrete", A thesis submitted to School of Graduate Studies of Addis Ababa University in partial fulfillment of the requirements for the degree of Master of Science in Civil Engineering (Road and Transport Engineering)

[49] Mathew, T.V., \& Rao, K.V. (2007) Pavement Materials: Bitumen. In Introduction to Transportation Engineering. Retrieved March, 2018, from: https://nptel.ac.in/course.php

[50] Matthew, T.V. (2015). 9 Test to Check Quality of Bitumen for use in Road Work. Retrieved March, 2018, from: http://civilblog.org/2015/09/11/9-test-to-check-quality-of-bitumen-for-use-in-road-work/

[51] Mississippi Asphalt Pavement Association MAPA, (2017). Asphalt Paving Design Guide. Retrieved March, 2018 from: http://msasphalt.com/wp-content/uploads/2017/05/2017_MAPA_Design.pdf

[52] Minnesota Asphalt Pavement Association MAPA, (no date). Asphalt Paving Design Guide. Retrieved March, 2018 from: https://www.asphaltisbest.com/wp.../MAPA-Asphalt-Paving-Design-Guide_web.pdf (28/3/2018)

[53] Papadopoulos, A.M. (2005). State of the art in thermal insulation materials and aims for future developments. Energy and Building, 37(1): 77-86.

[54] Pasadin, A.R.; Perez, I. The influence of the mineral filler on the adhesion between aggregates and bitumen. International Journal of Adhesion and Adhesives, 58, 53-58.

[55] Putri, A.M.\& Suparma L.B. (2009). Laboratory study on the durabilitycharacteristics (moisture damage evaluation) of asphalt concrete wearingcourse (AC-WC) Ytilizing Bantak and Clerang as aggregate (using Marshal methods) proceedings of the Eastern Asia Society for TransportationStudies, vol. 7, 2009 
Contributions of Periwinkle Shell Ash on the Stability and Elastic Properties of Modified Asphalt Concrete for a High Trafficked Road

[56] Puzinauskas, V.P. (1983). Filler in Asphalt Mixtures; Asphalt Institute: Lexington, KY, USA, 1983.

[57] Rahman, M. (2004). Characterization of Dry Process Crumb Rubber Modified Asphalt Mixtures. Unpublished Dissertation, Nottingham: University of Nottingham

[58] Ratnasamy, M., Eltaher, A., (2003). The effect of type and particle size of industrial wastes filler on Indirect Tensile Stiffness and Fatigue performance of S.M.A. Mixtures AustralianState Organization of Roads, and Bridges Specifications (SORB /R9), Chapter 9, 2003

[59] Robbins, M. (2009). An Investigation Into Dynamic Modulus Of Hot-Mix Asphalt And Its Contributing Factors. Masters Dissertation, University of Toledo, 2005

[60] Sadoon O.E. (2012). The influence of Filler Type on Asphalt Mastic and Performance Properties of Asphalt Paving Materials. M.Sc. Thesis, College of Engineering, University Anbar, 2010.

[61] Sangiori, C., Tataranni, P., Mazzotta, F., Simone, A., Vignali, V., \& Lantieri, C. (2017). Alternative Fillers for the Production of Bituminous Mixtures: A Screening Investigation on Waste Powders. Coatings Journal, 7:76, 1-14.

[62] Shanbara, H.k., Ruddock, F., Atherton, W., \& Nassir, N.A. (2018). Mechanical Properties of Ordinary Portland Cement Modified Cold Bitumen Emulsion Mixture. International Journal of Civil and Environmental Engineering, 12:5, 2018

[63] Sofia G.G. (1986). The Effect of Dust Fines on the Properties of Asphalt Paving Mixtures, M.Sc. Thesis, College of Engineering, University of Mosul, 1986.

[64] Terrel, R.L., \& Jean, W.L. (1986). Modified Asphalt pavement Materials: the European experience. Association of Asphalt Paving Technologists, 1: 482-518

[65] Wess, J.A., Olsen, L.D., \& Sweeney, M.H. (2004). Asphalt (Bitumen). Geneva: World Health Organization.

[66] Witczak, M.W., Kaloush, K., Pellinen, T., El-Basyouny, M. \& Von Quintus, H. (2002).NCHRP Report 465, Simple Performance Test for Superpave Mix Design. TransportationResearch Board, National Research Council. Washington,D.C. http://gulliver.trb.org/publications/nchrp/nchrp_rpt_465.pdf

[67] Zulkati, A., Diew, W.Y. \& Delai, D.S. (2012). Effects of fillers on properties of asphalt-concrete mixture. Journal of Transportation Engineering, 138, 902-910.

Citation: Kemejika Ichechi, et.al, "Contributions of Periwinkle Shell Ash on the Stability and Elastic Properties of Modified Asphalt Concrete for a High Trafficked Road”, International Journal of Constructive Research in Civil Engineering, 6(2), pp. 1-10. DOI: http://dx. doi.org/10.20431/2454-8693.0602001.

Copyright: (C) 2020 Authors, This is an open-access article distributed under the terms of the Creative Commons Attribution License, which permits unrestricted use, distribution, and reproduction in any medium, provided the original author and source are credited. 